\title{
Methods to Assess Economic Loss while Implementing Energy Saving Programs in Oil-Production Enterprises
}

\author{
Valitov Sh.M. \\ Kazan Federal University, Institute of Management, Economics and Finance, Kazan, 420008, Russia \\ Mingaleev G.F. \\ Kazan National Research Technical University named after A.N.Tupolev, Kazan, 420111, Russia \\ Khadeev N.R. \\ JSC “Nasko-Tatarstan", Russia, 420094, Kazan,
}

Antonova N.V.

Kazan Federal University, Institute of Language, 420008, Kazan, Russia

\section{Doi:10.5901/mjss.2015.v6n3p766}

\begin{abstract}
To justify energy-saving measures in certain oil-production enterprises it is necessary to classify facilities, social and economic results of energy saving and means of their achievement to validate the system of energy-saving efficiency in oil sector. It is essential to take into account the peculiarities of the economic efficiency of the set of energy-saving measures which are determined by the specific character of energy efficiency at different stages of the process and take place in production, treatment and transportation of oil in oil-production enterprises.
\end{abstract}

Keywords: energy saving, oil company, complex measures, programs and goals planning, ranking, loss index.

Oil production is quite an energy consuming industrial area with a steady tendency towards increase in power consumption due to the increasing demand for water injection to oil reservoirs in order to maintain reservoir pressure and recover floating oil, as well as because of the growing water cut. Energy cost in oil-and-gas production enterprises is higher than average across the industry. There is a set of factors, such as: high level of oil field development; increase in water encroachment into gas and oil, and volume of the liquid produced; need to change the ratio of crude oil production from terrigenous deposits towards increase in oil recovery from carbonate reservoirs, due to which oil production and shipping costs as well as expenditures for oil treatment are increasing from year to year. This fact has been constantly referred to by various authors in their analytical works on energy conservation [1, 2]. Inevitable increment in energy costs in oil production enterprises necessitates appropriate steps to reduce or at least stabilize them.

The authors propose to take into consideration the peculiarities of assessing cost-effectiveness of activities according to the resulting energy-conservation effect in following spheres: field development; oil extraction; manufacturing equipment optimization, including power equipment; petroleum treatment and refining; oil skimming and transportation; fleet vehicles upgrading. These peculiarities need to be taken into account in calculations. Alterations should be introduced while assessing cost and profit fraction of the business caused by possible economic and financial consequences of implementing energy conservation measures through energy-efficiency programme.

For example, in the course of oil field development the following actions can be taken: shutting down oil wells due to high water-cut, restricted water injection, bottom-hole treatment, handling insulating works in oil wells, pumping polimer-gel system into injection wells. These can reduce variable expenses in various aspects: energy to lift the liquid to the surface, oil skimming and transportation, maintaining equipment, reservoir pressure maintaining; opportunity to drive down costs or conduct additional remedial works thanks to incremental oil production and profit, release funds for social needs. Power consumption goes down; so do energy costs; power charge changes, as well as demand charge. These steps boost reservoir recovery without increasing volumes of produced water, reduce the amount of liquid taken off and enhance oil extraction, cut variable costs which depend on fluid produced, improve both environmental and life safety. 
For example, during oil recovery stage electric submersible pumps can be replaced by sucker-rod pumping systems; regular pumping out can be conducted. This leads to energy saving due to lowering standby losses of basic equipment in power facilities and permits removal of uneconomic equipment. These factors actually establish conditions for re-equipment and promote operational safety. Another positive effect is reduction in expenses for energy and revamping due to cutting well operation time and prolonging intervals. Such step as adopting polymer coating, scratchalizers and bottom-hole batch meters, reduces if not removes a great deal of distillation procedures and cuts costs on their fulfillment, drives down costs on remedial works caused by wax accumulation and reduces their number, lowers underperformance associated with intervals for oil treatment and increases profit; saves working hours and improves labor force efficiency.

Significant effect may be generated through rational choice and replacement of equipment. The more characteristic steps are the following:

replacing more power transformers by those with lower power,

network reconstruction,

substituting cross sections and material, shortening electrical cables,

replacing asynchronous motors by synchronous ones,

replacing more powerful raw oil pumps by less powerful ones,

replacing double reduction gears on rod-well pumps by triple reduction ones.

These steps can lead to the following positive results: loss reduction and energy saving, lower costs on idle energy component, reduced power consumption, heat accounting, reduced heating medium temperature in heating systems in industrial buildings and office blocks at weekends, on holidays and at night. This leads to:

heat economy and reduced expenditures for heating energy,

increase in profit due to reduction in operational expenditures,

environmental improvement,

improvement in ecosystem and public health, thanks to reduction in air contaminants resulting from fuel combustion.

Oil treatment and refining implies a need for condensate return from heat consumers as well as heating and ventilation systems. This leads to sustainable use and economy of heat, lower costs of heat energy. Heat consuming equipment and network insulation in its turn results in lower heating energy costs, enhanced reliability and endurance of heating systems and equipment operation. Adoption of water boilers can prevent heat wastes associated with condensed water, which are common in steam boilers, save heat and cut heating costs.

Long-life pipes used in oil skimming and transportation have the following advantages: decline in the number of pipeline ruptures and expenses for their elimination, increase in service life and net profit by preventing underperformance, energy conservation, environmental improvement, better living conditions, lower staff morbidity rate.

Energy saving potential can be realized, for example, in fleet vehicles by merely converting gasoline cars to gas.

Below, we will present several externalities resulting from improving efficiency of energy resources in an oilproduction enterprise. They include: raising efficiency of crew bus utilization, fuel conservation, improvement in environment and ecosystems, saving fuels and lubricants, lowering operational expenditures, improving comfortability and living environment.

Implementation of energy conservation programme in certain industrial enterprises requires a relevant methodological and procedural framework to demonstrate technical and economic feasibility of adopting energyconservation measures. Any delays in implementing them cause substantial economic dis-benefit and have an adverse effect on ecological situation. Besides, cost increase in oil production industry, as well as in other sectors of national economy, is associated with the increasing lack of funds, which holds back equipment and technological upgrade in step with technological progress. Thus, to avert financial losses while creating energy-saving strategies we need to develop an assessment method for energy-efficiency programmes considering available financial resources for their implementation. Therefore, to hold down inevitable growth of energy costs in oil production, caused by external reasons mentioned above, it is necessary to create and adopt energy-saving measures based on the methods of programme and goal-oriented energy-saving planning in oil-production enterprises.

However, a contradiction arises while creating and implementing the strategies. On the one hand, there are financial restrictions in creating and implementing the programmes, on the other, any delays in their adoption might lead to significant economic losses. Along with the indicated factors, there is considerable lack of motivation to save energy among power consumers.

This process is driven by both information threshold and traditionally cautious attitude of factory management towards innovations. Hence, in this case the problem is not confined to the question where to raise funds (which are 
usually declared in programmes as a mere amount to be invested in the given actions), but also raises the issue of reducing initial investment volume and making efficient use of it while carrying out the energy-conservation programme in the enterprise. Selective financing of operations having direct or indirect energy saving effect (whose primary target is to create demonstration zones or randomly copy them) cannot pave the way for efficient economic policy in this sphere and does not help achieve the key objective, i.e. reduce energy consumption in manufacturing operations. Therefore we need to implement research-backed methods to reduce (maintain) this element, which permit cutting economic losses while developing and carrying out energy efficiency programmes. Thus, to create efficient energy-conservation programmes we do not only need to adopt a set of energy-saving activities, provided there is funding available for this purpose, but also create methods to set out the sequence of their adoption. For this purpose, we can optimize investment allocation into various energy-efficiency measures. The key objective of sequencing their implementation appropriately is to evaluate their assessment criteria, which makes it possible to identify the alterative action that will cause major losses (financial, power and environmental), with due consideration to the investment volume.

The authors propose to estimate these losses using an index which represents the ratio of net present value reduction in the period following the present, as a result of putting off current energy-efficiency measures, to volume of investments into energy conservation. Therefore, the index of losses caused by putting off energy efficiency measures can be expressed as follows:

$$
J_{P E}=\frac{\sum_{i=1}^{n} \frac{P V_{i}}{(1+r)^{i}}-\sum_{i=1}^{n} \frac{P V_{i}}{(1+r)^{i+1}}}{\sum_{i=1}^{n} \frac{I_{i}}{(1+r)^{i}}},
$$

where $-l_{i}$ is the discounted energy efficiency investment flow (rubles); $r$ is the discount rate;

$J_{P E}$ is the index of losses caused by putting off energy efficiency measures from the present moment on to the succeeding period.

While ranking energy efficiency measures we should use the index in the following way: the higher the economic losses caused by putting off adoption of relevant measures are, the higher the rank is.

Therefore, the proposed method allows us to ignore subjectivity factor, inherent to the widely used Delphi approach (expert evaluation method). Nonetheless, we cannot assume that we can do without it while estimating efficiency of an action, since to assess index validity of any action we will require qualified professionals. The proposed index describes economic losses of the enterprise if the measures to be adopted are delayed.

The assessment can be conducted with the help of the obtained ranking index, considering all income and expenditure items (reduced pollution charge, budget replenishment, etc.). Assessing losses from a possible delay in one or more energy conservation measures using this index, we obtain a more accurate estimation of energy-saving potential on the chosen object. It is evident, that taking the existing approaches to evaluate the performance and rank the activities, it is rather hard to detect these economic effects with respect to energy efficiency. One of specific features characterizing the method developed and proposed here is the opportunity to lower upfront investments in energy conservation at the stage of developing target-oriented energy-conservation programmes. This can be done by creating an implementation plan for energy efficiency in accordance with program-oriented and goal-oriented approaches synchronized over time and resources, which can be adjusted to the current period, and are able to forecast possible future prospects. This way, while conducting action ranking we take into account energy efficiency in time, and using this method we can achieve the key objective which consists is optimal energy efficiency, despite lacking funds for this purpose and timing constraints because of daily losses caused by irrational utilization of energy resources.

\section{References}

Valitov Sh.M., Mingaleev G.F. Rezultatyi programmno-tselevogo planirovaniya energosberezheniya v Respublike Tatarstan. Sotsialnoekonomicheskie problemyi stanovleniya i razvitiya ryinochnoy ekonomiki: Tezisyi dokladov itogovoy nauchno-prakticheskoy konferentsii.- Kazan: KFEl, 2001.- S.6-11.

Melnik, A.N., Mustafina, O.N. (2014). The liberalization of electricity market in the system of measures for improving industrial enterprisers competitiveness: The case of Russia. Mediterranean Journal of Social Sciences, 5 (18 SPEC. ISSUE), pp. 293-298.

Hadeev N.R., Mingaleev G.F. Effektivnost metodov formirovaniya energosberegayuschih meropriyatiy. Molodezh i ekonomicheskaya nauka: Stati i tezisyi dokladov Respublikanskoy nauchnoy konferentsii molodyih uchenyih i studentov.- Kazan: KFEl, 2000.- S.5766.

KovalYov V.V. Finansovyiy analiz: Upravlenie kapitalom. Vyibor investitsiy. Analiz otchYotnosti. - M.: Finansyi i statistika, 2011. - 340 s. Valitov, S.M.,Sirazetdinova, A.Z. (2014). Project risks' management model on an industrial entreprise. Asian Social Science, 10 (21), pp. 
242-249.

Safiullin, M.R., Safiullin, A.R., Elshin, L.A.,Prygunova, M.I. Matrix approach to assessing competitiveness of regions: From methodology to practice. Asian Social Science, 10, pp. 47-56

Safiullin M.R., Safiullin A.R. Structural analysis of the dynamics of petrochemical cluster of Republic Tatarstan. Mediterranean Journal of Social Sciences vol. 5 № 24, November 2014, pp. 300-306 .

Valitov S.M., Nigmetzyanov A.A. Modern principles of financial services markets regulation as a response to the financial and economic crisis of 2008 // Mediterranean Journal of Social Sciences vol. 5 № 24, November 2014, pp. 285-293.

Melnik, A.N., Lukishina, L.V. (2014). The use of index approach for enterprise energy strategy formation. Mediterranean Journal of Social Sciences, 5 (18 SPEC. ISSUE), pp. 289-292. 